\title{
Quality of mackerel steaks with the effect of seed extracts during ice storage
}

\begin{abstract}
The present study investigates antioxidant properties and storage stability of grape seed extract (GSE) and papaya seed extract (PSE). The effect of heat showed significant decrease whereas wide range of $\mathrm{pH}$ showed increase in its antioxidant activity. The storage days study indicated that, there was slight change in antioxidant activity (AOA) of GSE. The fish steaks were subjected to dip treatment with the BHT, GSE and PSE, at concentration of $200 \mathrm{ppm}, 500 \mathrm{ppm}$ and $1000 \mathrm{ppm}$ respectively for $5 \mathrm{~min}$. The quality of the steaks was assessed using chemical, microbiological and sensory parameters. The reduction in hydroperoxide formation of steaks treated with GSE and PSE was found to be less by 57.75 and $33.44 \%$ respectively with respect to untreated samples. The percentage inhibition of malonaldehyde formation in steaks treated with GSE and PSE was recorded to be lower by 59.66 and $20.99 \%$ respectively, with reference to untreated samples on the 9th $d$ of ice storage. The dip treatment of GSE and PSE increased the shelf life of mackerel steaks up to 15days, during ice storage. Therefore, it can be concluded that, GSE and PSE can be used as a promising natural preservative for preservation of fish and fishery products.
\end{abstract}

Volume 4 Issue 5 - 2017

\author{
Faisal Rashid Sofi,' Raju CV,' Lakshmisha IP,' \\ Dhanapal K, ${ }^{2}$ Kawkabul Saba ${ }^{3}$ \\ 'Department of Fish Processing Technology, College of Fisheries, \\ KVAFSU, Mangalore, India \\ ${ }^{2}$ Department of Fish Processing Technology, College of Fishery \\ Science, SVVU, Muthukur, India \\ ${ }^{3}$ Department of Fishery Resource Management, College of \\ Fishery Science, SVVU, Muthukur, India
}

\begin{abstract}
Correspondence: Faisal Rashid Sofi, Department of Fish Processing Technology, College of Fisheries, KVAFSU, Mangalore-57500 I, Karnataka, India, Tel +9I 9676242253, Email dr.sofi786@gmail.com
\end{abstract}

Received: July 20, 2017 | Published: August 02, 2017

Keywords: grape seed extract, papaya seed extract, storage stability, antioxidant properties, indian mackerel steaks, ice storage

Abbreviations: GSE, grape seed extract; PSE, papaya seed extract; AOA, antioxidant activity; DPPH, 2,2-diphenyl-1picryl hydrazyl; PV, peroxide value; TBARS, thiobarbituric acid reactive substance; TVB-N, total volatile base nitrogen; TMA, trim ethylamine; FFA, free fatty acid; EPR, electron spin resonance; TPTZ, 2,4,6 tripyridyl-5-triazine; BHT, butylated hydroxyl toluene; FTC, ferric thiocyanate method; MDA, malondialdehyde; PV, peroxide value; CSC, chilled steaks control

\section{Introduction}

Fish quality is very subjective nature and is very complex concept ${ }^{1}$ which comprises biochemical, microbiological, nutritional and physiochemical attributes. The freshness of fish degrades after death due to various biochemical reactions such as changes in protein and lipid fractions and microbiological spoilage. This results in the deterioration of sensory quality and nutritional value of fish. Preservation of fish assumes greater importance to prevent the loss of nutritionally rich natural resource. Quality loss of fish may be caused by a wide range of reactions, some are predominantly chemical (e.g., oxidative rancidity, colour loss, and non-enzymic Maillard browning reactions), physical (e.g., movement of moisture, change in texture, evaporation of low molecular mass flavour compounds, and damage induced by freezing/thawing), enzymic (e.g., lipolytic rancidity, proteolysis, and enzymic browning reactions), and microbiological (i.e., food spoilage and food poisoning). ${ }^{2}$ These various reactions are therefore the targets for fish preservation. Quality loss may be prevented or minimized by a range of techniques, including the use of additives, in particular to interfere with oxidative chemical reactions and to prevent or delay microbial growth. To retard such a quality loss, synthetic antioxidants and antimicrobial substances have been used to decrease lipid oxidation and microbial spoilage during the processing and storage of fish and fish products. ${ }^{3}$ However, the use of synthetic antioxidants and antimicrobial compounds has raised questions regarding food safety and toxicity. ${ }^{4}$ The use of natural antioxidants is emerging as an effective methodology for controlling rancidity and limiting its deleterious consequences.

Grape seed is a by-product of the food industry, which is usually discarded as a waste and as such, presents a cheap source of natural antioxidant due to its phenolic content. ${ }^{5}$ Seeds constitute a considerable proportion of the grape, ranging from $38-52 \%$ on a dry matter basis and constitute $46-69 \%$ polyphenols. ${ }^{6}$ The antioxidant activity of grapes has been positively associated with their phenolic composition such as anthocyanins, flavonols, flavan-3-ols, procyanidins, and phenolic acids. ${ }^{7-9}$ These compounds have been shown to reduce hydroperoxide formation and inhibit lipid and protein oxidation. ${ }^{10}$ In addition to antioxidant properties, the grape seed phenolics have also displayed antimicrobial properties. ${ }^{11}$ The antimicrobial property of grape seed extract is due to core structure with 3,4,5-trihydroxy phenyl groups found in epigallocathecin, epigallocathechin-3ogallate, prodelphinidin and castalagin. ${ }^{12}$

Papaya (Carica papaya L.) is native of America but has now spread all over the tropical world. The central cavity contains large quantities of seeds that comprise about $15 \%$ of the wet weight of the fruit. ${ }^{13}$ The total global production of papaya averages about $10.0 \mathrm{mmt}$, and India and Brazil are the major producers with annual production of 3.6 and 1.9million metric tonnes, respectively. The fruit is rich in phytochemical, especially carotenoids and polyphenols. ${ }^{14}$ Besides its juicy pulp, the peel and seeds of papaya are valuable too. Papaya seeds are known to give several health benefits..$^{15}$ Although papaya peel and seeds have various uses, the Phytochemicals especially phenolic compounds in these parts of papaya have both antioxidative and antimicrobial properties. Despite of abundance of grape and papaya seeds in India, the extract from seed, has not been fully exploited, which can be used as an alternative natural antioxidant and antimicrobial agents in different food products. 
The overall objective of this study was to identify whether the addition of GSE and PSE can retard both lipid oxidation and microbial spoilage and to extend the shelf life of Indian mackerel steaks during ice storage. In addition, this study provides greater insight into the potential of GSE and PSE as and effective sources of antioxidant and antimicrobial compounds for fish processing industry and storage stability of the crude polyphenols at different $\mathrm{pH}$, storage and temperature.

\section{Material and methods}

\section{Chemicals}

2,2-diphenyl-1-picryl hydrazyl (DPPH), Linoleic acid, potassium per sulphate, Aluminum chloride, catechin, potassium ferric cyanide and Ferric chloride were purchased from Sigma Chemicals Co. (St. Louis,MO,USA). All solvents used were of analytical grade and obtained from E-Merck, Mumbai, India and chemicals were obtained from Sigma Chemical Co. (St. Louis, MO, USA).

\section{Preparation of grape and papaya seed extracts}

Grape seeds were collected from local juice centers while papaya seeds were purchased from local juice processing center in Mangalore, Karnataka, India. The samples were washed and cleaned with water and dried in hot air oven at $50^{\circ} \mathrm{C}$ for $72 \mathrm{~h}$. Dried grape and papaya seeds were ground to fine powder by kitchen grinder and stored in refrigerator before extraction.

Dried powder of grape and papaya seed was used for extraction of bioactive compounds. One hundred grams of each ground material were defatted by shaking three times with four volumes of petroleum ether in a rotary shaker (Orbitek Scigenics, India) for $1 \mathrm{~h}$. The residues obtained after filtration was dried overnight under a hood until all traces of petroleum ether were removed. The dried residues from each material were extracted three times with four volumes of $90 \%$ ethanol by rotatary shaker for $1 \mathrm{~h}$ and filtered by using filter paper. The combined filtrates from each material were concentrated in a rotary evaporator (Rotavap PBU-6D, India) and placed under a hood to remove the residual ethanol. The obtained aqueous extracts were frozen overnight and freeze-dried at $-60^{\circ} \mathrm{C}$ (Modulyod Freeze dryer 230, USA). The freeze- dried extracts were stored in air-tight containers at $5^{\circ} \mathrm{C}$ until used for the determination of antioxidant activity.

The fish steaks were subjected to dip treatment with the BHT, GSE and PSE, at concentration of 200ppm, 500ppm and 1000ppm respectively for $5 \mathrm{~min}$. The treated samples were wrapped and sealed in polythene bags, and stored in ice in an insulated box. A $5 \mathrm{~cm}$ thick layer of ice was put at the bottom, then steaks and ice were put alternately, and the upper most portion with a layer of ice. Care was taken to cover all the samples with ice. Insulated fish box was kept at room temperature $\left(28^{\circ} \mathrm{C}\right)$. Re-icing was done every day to supplement the loss due to melting, after proper draining of ice melt water. Samples were drawn once in $3 \mathrm{~d}$ for ice storage period of $15 \mathrm{~d}$.

\section{Methods}

\section{Determination of DPPH radical scavenging activity}

DPPH assay was performed according to the method of. ${ }^{16} \mathrm{~A}$ known volume of $1.5 \mathrm{ml}$ of extract was added to $1.5 \mathrm{ml}$ of $0.1 \mathrm{mM} \mathrm{DPPH}$ solution prepared in $99.5 \%$ ethanol and thoroughly mixed by using cyclomixer at high speed. The mixture was stored in dark at room temperature for $30 \mathrm{~min}$. After the incubation, the absorbance was measured at $517 \mathrm{~nm}$ using UV-VIS double beam spectrophotometer (UV-VIS Spectrophotometer, LaboMed, Inc., UK.). Lower absorbance of the reaction mixture indicates higher free radical scavenging activity. DPPH radical-scavenging activity was calculated and expressed in terms of percentage of DPPH free radicals scavenged using the following formula

$$
\text { DPPHradicalscavengingactivity }(\%)=1-\frac{A b s_{\text {Sample }}}{A b s_{\text {Control }}} \times 100
$$

\section{Determination of Ferric reducing antioxidant power}

The ability of the extracts to reduce ferric ions to ferrous ions was determined by the method as described by Oyaizu. ${ }^{17}$ An aliquot of $1 \mathrm{ml}$ was mixed with $2.5 \mathrm{ml}$ of $0.2 \mathrm{M}$ phosphate buffer ( $\mathrm{pH} 6.6$ ) and $2.5 \mathrm{ml}$ of $1 \%(\mathrm{w} / \mathrm{v})$ potassium ferricyanide. The mixture was incubated at $50{ }^{\circ} \mathrm{C}$ for $30 \mathrm{~min}$. After incubation, $2.5 \mathrm{ml}$ of $10 \%(\mathrm{w} / \mathrm{v})$ trichloroacetic acid was added. Finally, $2.5 \mathrm{ml}$ of the solution from the mixture was drawn and mixed with $2.5 \mathrm{ml}$ of distilled water and $0.5 \mathrm{ml}$ of $0.1 \%$ $(w / v)$ ferric chloride solution. After $10 \mathrm{~min}$ of reaction time, the absorbance of the resultant solutions was measured at 700nm using UV-VIS Spectrophotometer. Higher absorbance of the reaction mixture indicates higher reducing power.

\section{Determination of antioxidant activity using linoleic acid model}

Linoleic acid auto-oxidation inhibition activity of extracts was measured according to the method as described by Osawa et al..$^{18}$ One $\mathrm{ml}$ of extract, dissolved in $10 \mathrm{ml}$ of $50 \mathrm{mM}$ phosphate buffer $(\mathrm{pH} 7.0)$ was added to a solution of $0.13 \mathrm{ml}$ of linoleic acid and $10 \mathrm{ml}$ of $99.5 \%$ ethanol. The total volume was then adjusted to $25 \mathrm{ml}$ with distilled water. The mixture was incubated in a $30 \mathrm{ml}$ assay tube with a screw cap at $40 \pm 1^{\circ} \mathrm{C}$ for 5 days in an incubator. The dark room condition was maintained by wrapping with aluminum foil and thicker paper. The degree of oxidation of linoleic acid was measured using the ferric thiocyanate method. To $0.1 \mathrm{ml}$ of the reaction mixture, $4.7 \mathrm{ml}$ of $75 \%$ ethanol, $0.1 \mathrm{ml}$ of $30 \%$ ammonium thiocyanate, and $0.1 \mathrm{ml}$ of $20 \mathrm{mM}$ ferrous chloride solution prepared in $3.5 \% \mathrm{HCl}$ were added. After 3 mins of incubation, the color was measured at $500 \mathrm{~nm}$. Appropriate controls were maintained using ethanol. The antioxidative capacity to inhibit the peroxide formation in linoleic acid was expressed as follows

$$
\text { Lipidperoxidation inhibition }(\%)=1-\frac{A b s_{\text {Sample }}}{A b s_{\text {Control }}} \times 100
$$

\section{Chemical analysis}

Proximate composition was determined by $\mathrm{AOAC}^{19}$ method. Peroxide value (PV) and thiobarbituric acid reactive substance (TBARS) was estimated spectrophotometrically by Richards et al. ${ }^{20}$ and Buege et al. ${ }^{21}$ respectively. Total volatile base nitrogen (TVB-N) and trim ethylamine (TMA) were estimated by the micro diffusion method. ${ }^{22} \mathrm{pH}$ was determined according to APHA ${ }^{23}$ using a digital $\mathrm{pH}$ meter (Polytron system PT 2100, Kinematica, AG) after homogenizing $10 \mathrm{~g}$ of the fish sample with the same amount of distilled water. The 
Free Fatty Acid (FFA) content in the lipid extract was determined with improved titremetric method as described by AOAC. ${ }^{19}$

\section{Microbiological analysis}

Microbiological analysis of mackerel samples was done by taking $25 \mathrm{~g}$ of fish muscle aseptically and homogenized with $225 \mathrm{ml}$ of $0.85 \%$ normal, saline for one min. Then the homogenized sample was serially diluted using sterile $9 \mathrm{ml}$ diluents and plated in specific media. Total plate count, counts of Staphylococcus aureus, and E. coli count were enumerated as per the methods described by Surendran et al. ${ }^{24}$

\section{Sensory evaluation}

Sensory characteristics were evaluated for raw fish, treated whole mackerel and steaks using 9 point hedonic scale prescribed by Meilgaard et al. ${ }^{25}$ The overall impression of the product on the assessor was estimated by overall acceptability, by adding scores of all the attributes. A high score (9-7) was given to fish with no offodors, a score 5 to fish with flat and neutral odors and score below 5 corresponded to unacceptable quality.

\section{Statistical analysis}

The data were subjected to a one-way analysis of variance (ANOVA) and the significance of the difference between means were determined by Duncan's multiple range test $(p<0.05)$ using statistical software (Statsoft Inc., Tulsa, USA). Values expressed are means of three determinations \pm standard deviation.

\section{Results and discussion}

\section{DPPH $\square$ radical scavenging activity}

Antioxidant effectiveness is measured by monitoring the inhibition of oxidation of suitable substrate. In biological systems antioxidant effectiveness is classified into 2 groups viz evaluation of lipid peroxidation and measurement of free radical scavenging ability. This assay is based on the measurement of reducing ability of antioxidant towards DPPH radical. The ability can be evaluated by electron spin resonance (EPR) or by measuring the decrease of its absorbance. It is used to evaluate antioxidant activity of natural sources and degree of its discoloration is attributed to its hydrogen donating ability of the test compounds, which is indicative of their scavenging potential..$^{26}$ In the present investigation the DPPH scavenging activity of grape and papaya seed extracts at different concentration is shown in Figure 1. The activity of both the extracts increased with increase in concentration $(\mathrm{P}<0.05)$. At the same concentration used, the descending order of DPPH radical scavenging activity of the seed extract tested was as follows: GSE $>$ PSE. The DPPH radical activity of GSE increased upto 300ppm and thereafter the activity did not showed any further increase $(\mathrm{P}>0.05)$. Results suggests that BHA show highest radical scavenging activity of $97.33 \%$ compared to both the extracts, whereas GSE and PSE showed an activity of 87.02 and $61.43 \%$ respectively at $500 \mathrm{ppm}$. The high radical scavenging of GSE could be due to flavonoids that can perform scavenging action on free radicals (superoxide, hydroxyl and 1,1-diphenyl-2-picrylhydrazyl (DPPH)), metal chelating properties, reduction of hydroperoxide formation and their effects. ${ }^{27}$ The presence of the functional group "-OH" in the structure and its position of the flavonoid molecule determine the antioxidant capacity. ${ }^{28}$ Addition of -OH group to the flavonoid nucleus will enhance the antioxidant activity, While substitution by $-\mathrm{OCH}_{3}$ groups diminishes the antioxidant activity. The other reason for higher scavenging activity of GSE is due to high amount of total phenolic content and the presence of monomeric polyphenolic compounds such as (+)-cathecin , (-)-epicathecin and epicathecin-3-o-gallate and dimeric and tetrameric procyanidins. ${ }^{29}$

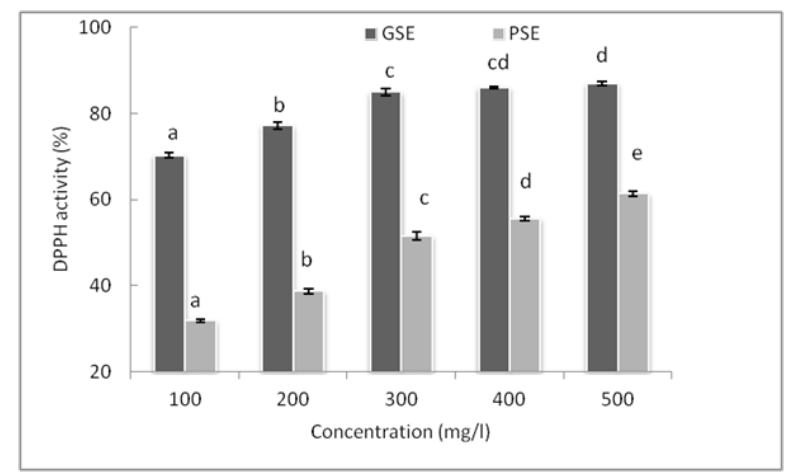

Figure I DPPH radical scavenging activity of GSE and PSE at various concentrations. Bar indicates Mean $\pm S D(n=3)$ \& bars with different letters are significantly different $(p<0.05)$.

The lower scavenging activity of papaya seed extracts could be due to P-hydrobenzoic acid and vanillic acid which are simple phenolic compounds as reported by Zhou et al.. ${ }^{30}$ The carboxyl group of hydrobenzoic acid and methoxy group of vanillic acid might explain negative effect on its antioxidative activity. The carboxyl group is the electron withdrawing group which doesn't benefit the radical scavenging activity of the compound. ${ }^{31}$ The result indicated that grape seed were the potential free radical scavengers, which reacted with radicals by donating their hydrogen and acts as primary antioxidants which can be used as a rich source of functional and antiradical compound to prevent lipid oxidation.

\section{Ferric reducing power assay}

Reduction capabilities of plant extracts can serve as a significant indicator of their potential antioxidant activities. This assay is based on the reaction which measures reduction of ferric $\left(\mathrm{Fe}^{3+}\right) 2,4,6$ tripyridyl5-triazine (TPTZ) to a colored ferrous $\left(\mathrm{Fe}^{2+}\right.$ (TPTZ) product. The $\mathrm{Fe}^{2+}$ formed from the reduction process was then monitored by measuring the formation of Perl's Prussian blue. Increasing absorbance of the reaction mixture at $700 \mathrm{~nm}$ indicates an increase in the reducing power; however, it is limited to hydrophilic antioxidants. This kind of reduction process is based on the tendency of an antioxidant to donate electron. ${ }^{32}$ The reducing ability of the GSE and PSE were

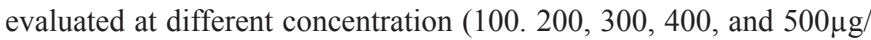
$\mathrm{ml}$ ) as shown in Figure 2 and were compared to standard Butylated hydroxyl toluene (BHT) at 200ppm. All the extracts were capable of reducing $\mathrm{Fe}^{3+}$ and did so in a linear dose dependent manner. Among the two extract tested, GSE showed highest ferric reducing activity at all concentration $(\mathrm{P}<0.05)$ and showed highest reducing power at $500 \mu \mathrm{g} / \mathrm{ml}$ which is almost equivalent to BHT at 200ppm., indicating that GSE could easily donate electron to $\mathrm{Fe}^{3+}$, thus reducing it to $\mathrm{Fe}^{2+}$. The ability of grape seed to show good reducing power is due to cathecin and epicathecin possessing the higher number of higher hydroxyl groups. The results of high reducing power of GSE were in agreement with highest DPPH and ABTS radical scavenging activity. Zhang et al. ${ }^{33}$ also reported that GSE was able to reduce $\mathrm{Fe}^{3+}$ to $\mathrm{Fe}^{2+}$ and with increase in concentration ferric reducing power increases. In Contrary papaya seed extract shows least reducing power and the results were in agreement with less Phenolic content, DPPH 
and ABTS radical scavenging activity. Zhau et al..$^{30}$ found that ethyl acetate extract of PSE possessed the greater reducing power than did ethanol extract fraction, $n$-butanol fraction and water fraction which is in accordance with the results of the current study. The results suggests reducing power of the compound appears to be related to degree of hydroxylation and extent of conjugation in polyphenols which is seen in GSE as it contain cathecin and epicathecin which are highly hydroxylated while in case of PSE it lacks hydroxylation in its structure, which could affect in ferric reducing ability.

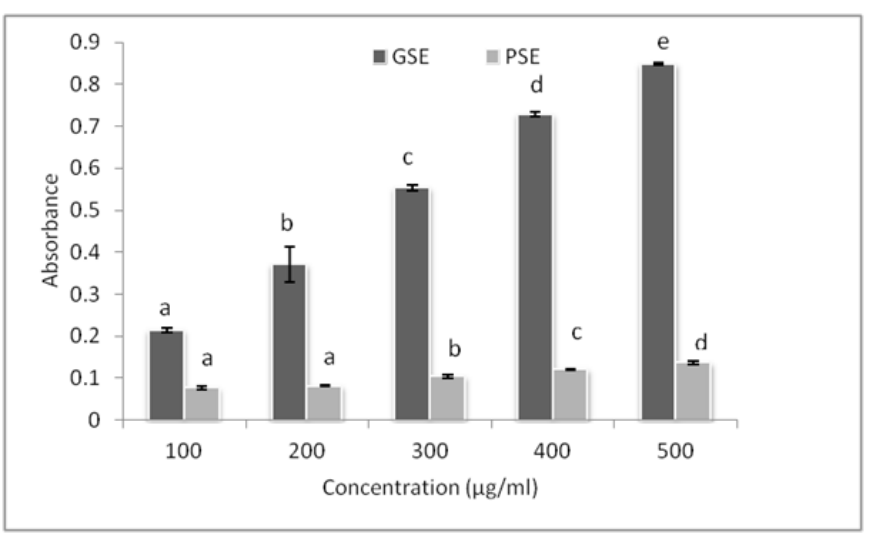

Figure 2 Ferric reducing antioxidant power (FRAP) of GSE and PSE at various concentration. Bar indicates Mean $\pm S D(n=3)$ \& bars with different letters are significantly different $(p<0.05)$.

\section{Antioxidant activity by linoleic acid emulsion system}

Lipids rich in unsaturated fatty acids are most susceptible to oxidative processes. Specially, Linoleic acid and arachidonic acid are targets of lipid Peroxidation. The inhibition of lipid peroxidation by antioxidants may be due to their free radical-scavenging activities. Superoxide indirectly initiates lipid peroxidation because superoxide anion acts as a precursor of singlet oxygen and hydroxyl radical. ${ }^{33}$ Hydroxyl radicals eliminate hydrogen atom from the membrane lipids, which results in lipid peroxidation.

Lipid oxidation inhibitory activity is been measured by ferric thiocyanate method (FTC). It measures amount of peroxide produced during initial stage of lipid oxidation. The FTC assay consists of ammonium thiocynate and $\mathrm{Fe}^{2+}$ in acidic solution. $\mathrm{H}_{2} \mathrm{O}_{2}$ induced by lipid oxidation oxidizes $\mathrm{Fe}^{2+}$ to $\mathrm{Fe}^{3+}$ resulting in the formation of a red colored $\mathrm{Fe}^{3+}$-thiocyanate complex. The levels of oxidation are determined by measuring the absorbance at $500 \mathrm{~nm} .{ }^{35,36}$ On the other hand, TBA measures the amount of Malondialdehyde (MDA) produced during the second stage of the lipid oxidation. This method is based on the MDA reaction with thiobarbituric acid to obtain a red pigment, resulting from the condensation of two molecules of TBA with one molecule of MDA. The levels of oxidation are determined by measuring the absorbance at $535 \mathrm{~nm}^{37,38}$

The inhibitory capacity of GSE and PSE against the oxidation of Linoleic acid model system was tested. As shown in Figure 3, the percentage of inhibition of lipid oxidation by grape and papaya seed was measured at three different concentrations. At the same concentration, grape seed was observed to have higher inhibitory activity $(\mathrm{P}<0.5)$ than papaya seed extracts and with the increase in concentration inhibitory activity of both the extracts increases with a maximum of 81.02 and $65 \%$ respectively for GSE and PSE. Ramachandani et al. ${ }^{39}$ so reported that, GSE could inhibit lipid peroxidation in the mouse liver microsome model system by $70-80 \%$. Moreover, Jayaprakasha et al. ${ }^{40}$ has reported that, the ethanolic and water grape seed showed $80 \%$ inhibition of the Linoleic peroxidation after $100 \mathrm{~h}$. The mechanism involved for interference of GSE inhibition of lipid oxidation is either iron chelating activity or by scavenging of superoxide radicals, which are responsible for reduction of ferric to ferrous, catalyzed by Fenton reaction and the iron chelating activity. ${ }^{39}$

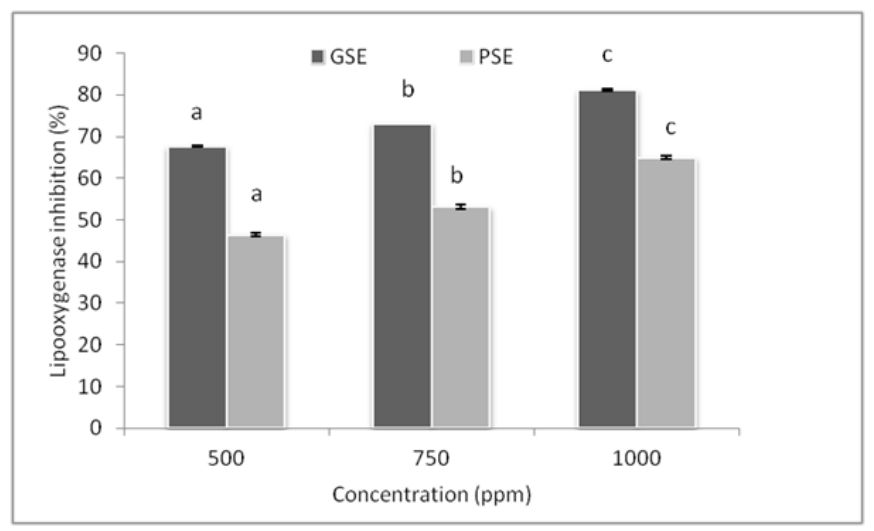

Figure 3 Inhibition of lipid oxidation in linoleic acid model system by GSE and PSE used at various concentrations. Bar indicates Mean \pm SD $(n=3)$ \& bars with different letters are significantly different $(p<0.05)$.

\section{Changes in antioxidant activity (AOA) of GSE and PSE with the effect of heat, $\mathrm{pH}$ and storage stability}

The ability to inhibit lipid oxidation differed according to the types of plant extract, oxidizable substrate used, thermal and $\mathrm{pH}$ treatment to which the extracts are subjected. It is well known that many factors such as antioxidant concentration, temperature and $\mathrm{pH}$ of the media, processing treatment and storage strongly influence the antioxidant activity. ${ }^{41}$ In the present study, changes in antioxidant activity in linoleic acid model system with the influence of heat, $\mathrm{pH}$ and storage stability were carried out.

\section{Effect of heat treatment on AOA of GSE and PSE in linoleic acid model system}

In the present study effect of heat treatment $\left(100^{\circ} \mathrm{C}, 15 \mathrm{~min}\right)$ on the antioxidant activity of GSE and PSE were determined in linoleic acid model system and the results are presented in Figure 4. The antioxidant activity of GSE and PSE without any heat treatment was found to be 67.67 and $46.43 \%$ respectively at $500 \mathrm{mg} / \mathrm{L}$. The heat treatment at $100^{\circ} \mathrm{C}$ for $15 \mathrm{~min}$ decreased the AOA of GSE and PSE and was found to be 52.16 and $46.43 \%$ respectively at $500 \mathrm{mg} / \mathrm{L}$. The decrease in AOA of both the extracts might be due to loss of naturally occurring antioxidants present in the extract or formation of novel compounds having prooxidant activity upon heating. Thermal processing can induce the formation of compounds with antioxidant properties or improve the AOA of naturally occurring antioxidants. ${ }^{42}$ The antioxidant activity of number of vegetable juices is reported to be stabilized by boiling, suggesting that the initial prooxidant activity is due to peroxidase which are inactivated at high temperatures. ${ }^{41}$ It is reported that crucifer extracts exhibit either a prooxidant or an antioxidant activity depending on the thermal processing and variety of vegetable examined. ${ }^{43} \mathrm{An}$ increase in AOA of carrot puree due to thermal processing is associated with increased levels of phenolic acids. $^{44}$ 


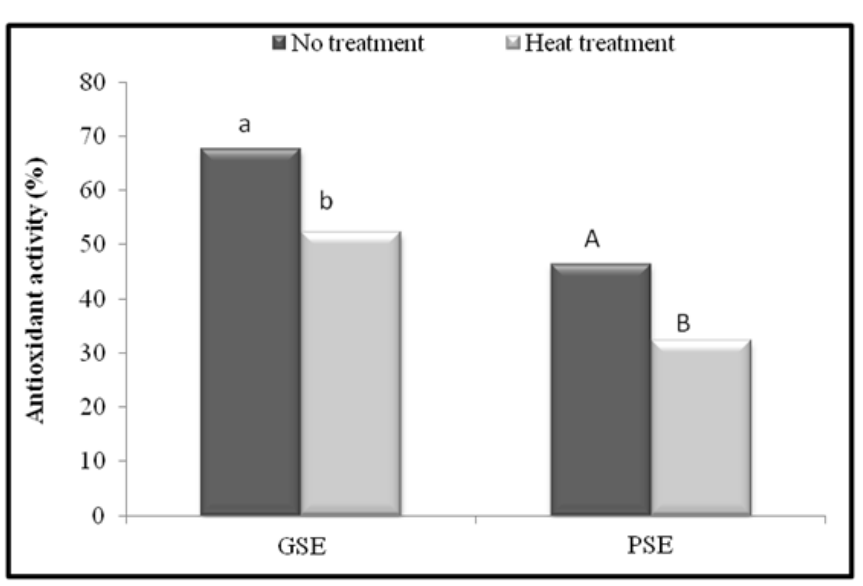

Figure 4 Effect of heat treatment $\left(100^{\circ} \mathrm{C}, 15 \mathrm{~min}\right)$ on antioxidant activity of GSE and PSE in linoleic acid model system at $500 \mathrm{mg} / \mathrm{L}$. Bars with different letters are significantly different $(p<0.05)$.

\section{Effect of pH on AOA of GSE and PSE in linoleic model system}

The antioxidant activity of GSE and PSE were seen in a wide range of $\mathrm{pH}(4,7$, and 9) at concentration of $500 \mathrm{mg} / \mathrm{L}$ and the results of the investigation are presented in Figure 5. The lipid peroxidation inhibition of GSE and PSE at $500 \mathrm{mg} / \mathrm{L}$ was recorded to be 67.67 and $46.43 \%$ respectively as shown in Table 2, 9A, 9B and Figure 2.The AOA of GSE was found to be $69.01,68.11$ and $72.18 \%$ at $\mathrm{pH} 4,7$ and 9 respectively, whereas, for PSE lipid peroxidation inhibition of $52.20,46.02$ and $54.06 \%$ at respective $\mathrm{pH}$. The significant difference in AOA of GSE and PSE were found maximum at $\mathrm{pH} 9$ while least at $\mathrm{pH} 7$, which indicates strong dependence of AOA on the $\mathrm{pH}$ system. Yen et $\mathrm{al} .{ }^{45}$ reported that a methanol extract from peanut hulls had a higher AOA at neutral acid $\mathrm{pH}$. The AOA of different extracts from cocoa by-products was higher at alkaline $\mathrm{pH}{ }^{46}$ These differences might be due to different samples used and various compounds being extracted in each case.

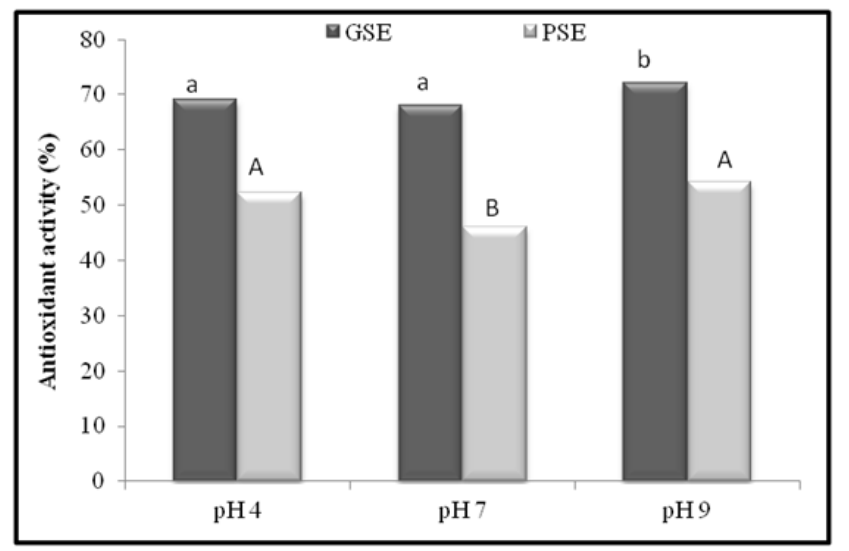

Figure 5 Effect of $\mathrm{pH}$ on antioxidant activity of GSE and PSE in linoleic acid at $500 \mathrm{mg} /$ L. Bars with different letters are significantly different $(p<0.05)$.

\section{Effect of storage time on AOA of GSE and PSE in linoleic acid model system}

The effect of storage time on the antioxidant activity of the GSE and PSE at $500 \mathrm{mg} / \mathrm{L}$ is shown in Figure 6 . The GSE and PSE were stored in the dark at 5 and $25^{\circ} \mathrm{C}$ and the lipid peroxidation inhibition of GSE and PSE at varied temperature and storage conditions were seen after $15 \mathrm{~d}$. The lipid peroxidation inhibition of GSE showed percentage inhibition of 67.42 and $64.13 \%$ at 5 and $25^{\circ} \mathrm{C}$ respectively while PSE showed lipid peroxidation inhibition of 46.66 and $46.40 \%$ at respective temperatures. The results of the study indicated that there was slight change in AOA of GSE with the change in storage time while antioxidant activity of PSE remains unchanged during entire storage period. The results of the present study indicated that, there was no change in AOA during the storage period. Saeedeh et al. ${ }^{47}$ observed that, the storage period did not show any significant difference in AOA of the plant extracts.

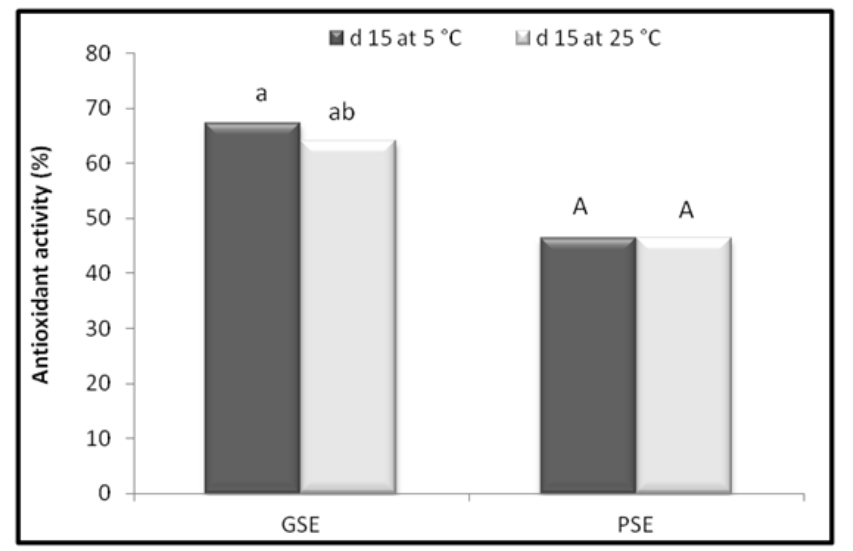

Figure 6 Effect of storage time at different temperatures on antioxidant activity of GSE and PSE in linoleic acid at $500 \mathrm{mg} / \mathrm{L}$. Bars with different letters are significantly different $(p<0.05)$.

\section{Chemical analyses}

Changes in peroxide value (PV): Peroxide value (PV) is a measure of the primary degree of oxidation in the fish muscle. ${ }^{48}$ The changes in PV of steaks treated with GSE and PSE showed lower hydroperoxide formation compared to untreated samples during ice storage as shown in Table 1. The PV of chilled steaks control (CSC) increased significantly throughout the storage period $(p<0.05)$ whereas hydroperoxide formation of treated groups was minimum. A reduction in hydroperoxide formation on the day of sensory rejection of chilled steaks control (CSC) was found less by $64.39,57.75$ and $33.44 \%$ for BHT, GSE and PSE treated steaks respectively. The results of the present study are in agreement with the findings of Jianyun et al. ${ }^{49}$ They documented that, phenolic compounds from grape seed and clove bud extracts lowers the increase in peroxide value of silver carp fillets during chilled storage. According to Sulochanan, ${ }^{50}$ phenolic compounds from natural sources like rosemary and clove extracts lower the peroxide value of Indian mackerel during 10d of storage in iced condition. The inhibition of peroxides is concentration-dependent which showed a direct relationship between the polyphenolic concentration and the inhibitory efficiency as studied by Bensid et al. ${ }^{51}$ During ice storage, polyphenolic concentration of 100ppm of GSE inhibited the formation of hydroperoxides about $95 \%$ as observed by Iglesias et al..$^{52}$ 
Table I Changes in PV, peroxide value; TBARS, thiobarbiuturic acid reactive substances; FFA, free fatty acid; TMA-N, trimethylamine nitrogen; TVB-N, total volatile base nitrogen; and $\mathrm{pH}$ of Indian mackerel steaks treated with GSE, grape seed extract; PSE, papaya seed extract during ice storage

\begin{tabular}{|c|c|c|c|c|c|c|c|}
\hline \multirow[b]{2}{*}{ Parameters } & \multicolumn{7}{|l|}{ Storage days } \\
\hline & Treatments & $\mathbf{0}$ & 3 & 6 & 9 & 12 & 15 \\
\hline \multirow{4}{*}{ PV( mg hydroperoxide $\mathrm{kg}^{-1}$ ) } & $\mathrm{CSC}$ & $\begin{array}{l}1.60 \pm \\
0.07^{\mathrm{a}}\end{array}$ & $2.91 \pm 0.24^{\mathrm{d}}$ & $5.33 \pm 0.09^{\mathrm{c}}$ & $9.48 \pm 0.30^{\mathrm{d}}$ & $\begin{array}{l}11.60 \pm \\
0.04^{\mathrm{d}}\end{array}$ & $\begin{array}{l}14.10 \pm \\
0.25^{\mathrm{c}}\end{array}$ \\
\hline & BHT & $\begin{array}{l}1.60 \pm \\
0.07^{\mathrm{a}}\end{array}$ & $1.85 \pm 0.43^{\mathrm{a}}$ & $2.34 \pm 0.32^{\mathrm{a}}$ & $3.28 \pm 0.14^{\mathrm{a}}$ & $4.13 \pm 0.11 \mathrm{a}$ & $5.73 \pm 0.22^{\mathrm{a}}$ \\
\hline & GSE & $\begin{array}{l}1.60 \pm \\
0.07^{\mathrm{a}}\end{array}$ & $2.02 \pm 0.35^{b}$ & $2.65 \pm 0.16^{\mathrm{a}}$ & $3.96 \pm 0.20^{\mathrm{b}}$ & $4.90 \pm 0.16^{\mathrm{b}}$ & $6.10 \pm 0.16^{\mathrm{a}}$ \\
\hline & PSE & $\begin{array}{l}1.60 \pm \\
0.07^{\mathrm{a}}\end{array}$ & $2.54 \pm 0.28^{\mathrm{c}}$ & $4.01 \pm 0.19^{b}$ & $6.02 \pm 0.17^{\mathrm{c}}$ & $7.72 \pm 0.26^{\mathrm{c}}$ & $9.87 \pm 0.42^{b}$ \\
\hline \multirow{4}{*}{$\begin{array}{l}\text { TBARS }(\mathrm{mg} \\
\text { malonaldehydekg-1) }\end{array}$} & $\mathrm{CSC}$ & $0.33 \pm 0.11^{\mathrm{a}}$ & $0.88 \pm 0.11^{\mathrm{c}}$ & $1.28 \pm 0.06^{\mathrm{c}}$ & $1.46 \pm 0.17^{\mathrm{c}}$ & $1.81 \pm 0.08^{\mathrm{c}}$ & $2.30 \pm 0.29^{\circ}$ \\
\hline & BHT & $\begin{array}{l}0.20 \pm \\
0.05^{\mathrm{a}}\end{array}$ & $0.24 \pm 0.07^{\mathrm{a}}$ & $0.34 \pm 0.07^{\mathrm{a}}$ & $0.50 \pm 0.15^{\mathrm{a}}$ & $0.62 \pm 0.13^{\mathrm{a}}$ & $0.73 \pm 0.0^{5 a}$ \\
\hline & GSE & $\begin{array}{l}0.22 \pm \\
0.06^{\mathrm{a}}\end{array}$ & $\begin{array}{l}0.34 \pm \\
0.07^{\mathrm{ab}}\end{array}$ & $0.50 \pm 0.12^{\mathrm{a}}$ & $0.59 \pm 0.12^{\mathrm{a}}$ & $0.73 \pm 0.05^{\mathrm{a}}$ & $0.86 \pm 0.11^{\mathrm{a}}$ \\
\hline & PSE & $\begin{array}{l}0.24 \pm \\
0.07^{\mathrm{a}}\end{array}$ & $0.52 \pm 0.09^{\mathrm{b}}$ & $0.78 \pm 0.12^{\mathrm{b}}$ & $0.98 \pm 0.05^{\mathrm{b}}$ & $1.27 \pm 0.12^{\mathrm{b}}$ & $1.43 \pm 0.16^{\mathrm{b}}$ \\
\hline \multirow{5}{*}{ FFA( $\%$ oleic acid $)$} & $\mathrm{CSC}$ & $\begin{array}{l}1.42 \pm \\
0.04^{\mathrm{a}}\end{array}$ & $2.41 \pm 0.21^{\mathrm{a}}$ & $4.48 \pm 0.25^{\mathrm{a}}$ & $6.14 \pm 0.21^{\mathrm{b}}$ & $7.33 \pm 0.06^{\mathrm{b}}$ & $8.60 \pm 0.24^{b}$ \\
\hline & BHT & $\begin{array}{l}1.42 \pm \\
0.04^{\mathrm{a}}\end{array}$ & $2.01 \pm 0.15^{\mathrm{a}}$ & $4.04 \pm 0.11^{\mathrm{a}}$ & $5.36 \pm 0.26^{\mathrm{a}}$ & $6.48 \pm 0.17^{\mathrm{a}}$ & $7.09 \pm 0.17^{\mathrm{a}}$ \\
\hline & & & & & & & \\
\hline & GSE & $\begin{array}{l}1.42 \pm \\
0.04^{\mathrm{a}}\end{array}$ & $2.30 \pm 0.13^{\mathrm{a}}$ & $4.08 \pm 0.22^{\mathrm{a}}$ & $\begin{array}{l}5.10 \pm \\
0.252 \mathrm{a}\end{array}$ & $\begin{array}{l}6.70 \pm \\
0.13^{\mathrm{ab}}\end{array}$ & $\begin{array}{l}7.25 \pm \\
0.31^{\mathrm{ab}}\end{array}$ \\
\hline & PSE & $\begin{array}{l}1.42 \pm \\
0.04^{\mathrm{a}}\end{array}$ & $2.48 \pm 0.24^{\mathrm{a}}$ & $4.30 \pm 0.27^{\mathrm{a}}$ & $5.81 \pm 0.11^{\mathrm{ab}}$ & $7.14 \pm 0.13^{b}$ & $8.31 \pm 0.14^{b}$ \\
\hline \multirow{4}{*}{ TMA-N (mg N2 100g $\mathrm{g}^{-1}$ ) } & $\mathrm{CSC}$ & $\begin{array}{l}3.01 \pm \\
0.22^{\mathrm{a}}\end{array}$ & $5.25 \pm 0.13^{\mathrm{c}}$ & $7.17 \pm 0.20^{c}$ & $\begin{array}{l}11.36 \pm \\
0.14^{\mathrm{d}}\end{array}$ & $\begin{array}{l}15.28 \pm \\
0.02^{\mathrm{d}}\end{array}$ & $\begin{array}{l}19.99 \pm \\
0.24^{\mathrm{d}}\end{array}$ \\
\hline & BHT & $\begin{array}{l}3.01 \pm \\
0.22^{\mathrm{a}}\end{array}$ & $3.81 \pm 0.12^{\mathrm{a}}$ & $4.61 \pm 0.24^{\mathrm{a}}$ & $6.79 \pm 0.19^{a}$ & $9.36 \pm 0.44^{\mathrm{a}}$ & $\begin{array}{l}12.28 \pm \\
0.40^{\mathrm{a}}\end{array}$ \\
\hline & GSE & $\begin{array}{l}3.01 \pm \\
0.22^{\mathrm{a}}\end{array}$ & $4.15 \pm 0.22^{b}$ & $5.74 \pm 0.20^{\mathrm{b}}$ & $8.91 \pm 0.42^{b}$ & $11.4 \pm 0.32^{\mathrm{b}}$ & $\begin{array}{l}13.72 \pm \\
0.21^{\mathrm{b}}\end{array}$ \\
\hline & PSE & $\begin{array}{l}3.01 \pm \\
0.22^{\mathrm{a}}\end{array}$ & $4.22 \pm 0.12^{\mathrm{b}}$ & $5.95 \pm 0.16^{\mathrm{b}}$ & $9.22 \pm 0.12^{\mathrm{c}}$ & $\begin{array}{l}12.28 \pm \\
0.11^{\mathrm{c}}\end{array}$ & $\begin{array}{l}14.95 \pm \\
0.10^{\mathrm{c}}\end{array}$ \\
\hline \multirow{4}{*}{ TVB-N( mg N2 100g $\left.\mathrm{g}^{-1}\right)$} & $\mathrm{CSC}$ & $\begin{array}{l}8.10 \pm \\
0.47^{\mathrm{a}}\end{array}$ & $\begin{array}{l}14.97 \pm \\
0.20^{\mathrm{c}}\end{array}$ & $\begin{array}{l}24.18 \pm \\
0.99^{b}\end{array}$ & $\begin{array}{l}30.10 \pm \\
1.13^{\mathrm{c}}\end{array}$ & $\begin{array}{l}34.13 \pm \\
0.12^{\mathrm{d}}\end{array}$ & $\begin{array}{l}40.10 \pm \\
0.16^{\mathrm{d}}\end{array}$ \\
\hline & BHT & $\begin{array}{l}8.10 \pm \\
0.47^{\mathrm{a}}\end{array}$ & $8.42 \pm 0.24^{\mathrm{a}}$ & $\begin{array}{l}11.87 \pm \\
0.87^{\mathrm{a}}\end{array}$ & $\begin{array}{l}18.20 \pm \\
0.20^{\mathrm{a}}\end{array}$ & $\begin{array}{l}24.04 \pm \\
0.25^{\mathrm{a}}\end{array}$ & $\begin{array}{l}30.32 \pm \\
0.77^{\mathrm{a}}\end{array}$ \\
\hline & GSE & $\begin{array}{l}8.10 \pm \\
0.47^{\mathrm{a}}\end{array}$ & $\begin{array}{l}10.09 \pm \\
0.16^{\mathrm{b}}\end{array}$ & $\begin{array}{l}14.07 \pm \\
0.59^{\mathrm{a}}\end{array}$ & $\begin{array}{l}21.87 \pm \\
1.36^{\mathrm{b}}\end{array}$ & $\begin{array}{l}26.56 \pm \\
0.56^{\mathrm{b}}\end{array}$ & $\begin{array}{l}32.10 \pm \\
0.09^{\mathrm{b}}\end{array}$ \\
\hline & PSE & $\begin{array}{l}8.10 \pm \\
0.47^{\mathrm{a}}\end{array}$ & $\begin{array}{l}11.06 \pm \\
0.06^{\mathrm{b}}\end{array}$ & $\begin{array}{l}14.92 \pm \\
0.65^{\mathrm{a}}\end{array}$ & $\begin{array}{l}23.38 \pm \\
0.27^{\mathrm{b}}\end{array}$ & $\begin{array}{l}30.22 \pm \\
0.35^{\mathrm{c}}\end{array}$ & $\begin{array}{l}36.14 \pm \\
0.22^{\mathrm{c}}\end{array}$ \\
\hline \multirow{4}{*}{$\mathrm{pH}$} & $\mathrm{CSC}$ & $\begin{array}{l}6.17 \pm \\
0.01^{\mathrm{bc}}\end{array}$ & $6.32 \pm 0.00^{\mathrm{b}}$ & $6.52 \pm 0.01^{\mathrm{d}}$ & $6.60 \pm 0.01^{\mathrm{d}}$ & $6.72 \pm 0.02 c$ & $6.82 \pm 0.02^{c}$ \\
\hline & BHT & $\begin{array}{l}6.15 \pm \\
0.02^{\mathrm{b}}\end{array}$ & $6.20 \pm 0.01^{\mathrm{b}}$ & $6.24 \pm 0.01^{b}$ & $6.31 \pm 0.02^{b}$ & $6.40 \pm 0.02^{b}$ & $6.50 \pm 0.01^{b}$ \\
\hline & GSE & $\begin{array}{l}5.73 \pm \\
0.03^{\mathrm{a}}\end{array}$ & $5.93 \pm 0.02^{\mathrm{a}}$ & $6.09 \pm 0.02^{\mathrm{a}}$ & $6.23 \pm 0.02^{\mathrm{a}}$ & $6.35 \pm 0.03^{a}$ & $6.41 \pm 0.01^{\mathrm{a}}$ \\
\hline & PSE & $\begin{array}{l}6.15 \pm \\
0.02^{\mathrm{b}}\end{array}$ & $6.20 \pm 0.01^{b}$ & $6.33 \pm 0.01^{\mathrm{c}}$ & $6.40 \pm 0.01^{\mathrm{c}}$ & $6.42 \pm 0.03^{b}$ & $6.52 \pm 0.04^{b}$ \\
\hline
\end{tabular}


Table 2 Changes in drip loss, total plate count and sensory attributes of Indian mackerel steaks with the effect of GSE, grape seed extract; and PSE, papaya seed extract; during ice storage mean $\pm s d, n=3$; a-d Values in the same column for each attribute are followed by different letters are significantly different ( $<0.05$ )

\begin{tabular}{|c|c|c|c|c|c|c|c|}
\hline Parameters & Treatments & $\mathbf{0}$ & 3 & 6 & 9 & 12 & 15 \\
\hline \multirow{4}{*}{ Total plate count $(\log \mathrm{cfu} / \mathrm{g})$} & $\mathrm{CSC}$ & $4.60 \pm 0.07^{\mathrm{c}}$ & $5.30 \pm 0.08^{\mathrm{c}}$ & $6.20 \pm 0.14^{\mathrm{c}}$ & $7.30 \pm 0.27^{\mathrm{c}}$ & $8.30 \pm 0.13^{\mathrm{c}}$ & $8.70 \pm 0.33^{c}$ \\
\hline & BHT & $4.10 \pm 0.15^{\mathrm{b}}$ & $4.30 \pm 0.07^{\mathrm{b}}$ & $5.20 \pm 0.09^{b}$ & $5.70 \pm 0.14^{\mathrm{b}}$ & $6.80 \pm 0.16^{\mathrm{b}}$ & $7.70 \pm 0.1^{4 \mathrm{~b}}$ \\
\hline & GSE & $3.50 \pm 0.12^{\mathrm{a}}$ & $4.00 \pm 0.04^{\mathrm{a}}$ & $4.50 \pm 0.05^{\mathrm{a}}$ & $4.90 \pm 0.08^{\mathrm{a}}$ & $6.00 \pm 0.09^{\mathrm{a}}$ & $6.60 \pm 0.09^{\mathrm{a}}$ \\
\hline & PSE & $4.10 \pm 0.03^{\mathrm{b}}$ & $4.40 \pm 0.05^{b}$ & $5.40 \pm 0.07^{b}$ & $5.90 \pm 0.07^{b}$ & $6.90 \pm 0.08^{b}$ & $7.60 \pm 0.01^{b}$ \\
\hline \multirow{4}{*}{ Overall acceptability score } & $\mathrm{CSC}$ & $9.00 \pm 0.05^{\mathrm{a}}$ & $8.07 \pm 0.05^{\mathrm{a}}$ & $6.94 \pm 0.03^{\mathrm{a}}$ & $5.27 \pm 0.04^{\mathrm{a}}$ & $4.06 \pm 0.06^{\mathrm{a}}$ & $2.12 \pm 0.06^{\mathrm{a}}$ \\
\hline & BHT & $9.00 \pm 0.05^{\mathrm{a}}$ & $9.00 \pm 0.04^{\mathrm{c}}$ & $8.35 \pm 0.04^{\mathrm{d}}$ & $7.82 \pm 0.02^{\mathrm{d}}$ & $6.71 \pm 0.03 c$ & $5.88 \pm 0.06^{\mathrm{c}}$ \\
\hline & GSE & $9.00 \pm 0.05^{\mathrm{a}}$ & $8.92 \pm 0.04^{c}$ & $8.05 \pm 0.04^{\mathrm{c}}$ & $7.64 \pm 0.12^{\mathrm{c}}$ & $6.64 \pm 0.07^{\mathrm{c}}$ & $5.77 \pm 0.10^{c}$ \\
\hline & PSE & $9.00 \pm 0.05^{\mathrm{a}}$ & $8.24 \pm 0.04^{b}$ & $7.65 \pm 0.06^{\mathrm{b}}$ & $6.64 \pm 0.04^{b}$ & $5.43 \pm 0.02^{\mathrm{b}}$ & $5.04 \pm 0.07^{\mathrm{b}}$ \\
\hline
\end{tabular}

Changes in thiobarbituric acid reactive substances (TBARS): The TBARS value is an index of secondary lipid oxidation measuring malonaldehyde content. Malonaldehyde is a secondary product of oxidation resulting from the degradation of lipid hydroperoxides formed during the oxidation process of polyunsaturated fatty acids. ${ }^{37}$ The TBARS values of steaks among the treatments at $0^{\text {th }} \mathrm{d}$ did not differ significantly $(p>0.05)$ as shown in Table 1 and Figure 2 . However, the TBARS values of all treatments were significantly lower than that of the control $(\mathrm{CSC})(\mathrm{p}<0.05)$ during $15 \mathrm{~d}$ of ice storage. The percentage inhibition of malonaldehyde formation treated with GSE and PSE was recorded to be 59.66 and $20.99 \%$ respectively whereas, BHT showed marginal reduction of $65.57 \%$ with respect to untreated samples on the $9^{\text {th }} \mathrm{d}$ of ice storage. The above results clearly indicated that GSE at $500 \mathrm{mg} / \mathrm{L}$ can be compared with that of BHT at $200 \mathrm{mg} / \mathrm{L}$ whereas, PSE did not show promising effect in limiting the malonaldehyde formation. The above findings of PSE are in agreement with the in vitro antioxidant properties of papaya seed extract. Rababah et al..$^{53}$ and Shirahigue et al. ${ }^{54}$ observed, a marginal reduction in TBARS in chicken meat with the effect of GSE during refrigerated storage. According to Jongberg et al., ${ }^{55}$ GSE at 500ppm showed strong antioxidant activity in lowering TBARS formation in chill stored beef patties. The results of the present work follow similar trend of lowering TBARS formation as investigated by Brannan et al. ${ }^{56}$ They monitored the secondary lipid oxidation in chicken samples treated with GSE at $0.1 \%$ to $1.0 \%$ and concluded that, the higher percentage of phenolic compounds from GSE were more effective in lowering secondary lipid oxidation.

Changes in free fatty acids (FFA): It is well known that, the free fatty acid (FFA) is a result of enzymatic decomposition of lipids in fish and fishery products. ${ }^{41}$ Free fatty acids which cause protein denaturation are formed during processing as a result of lipid hydrolysis. The free fatty acid formation in steaks treated with BHT, GSE and PSE was reduced by $11.59,8.59$ and $2.59 \%$ as oleic acid respectively with respect to untreated steaks. The above result clearly indicated that, the effect of treatment had minimum inhibition on lipid hydrolysis and among the two seed extracts tested, inhibition on enzymatic hydrolysis was more pronounced in GSE treated samples compared PSE treated samples. The result of the present study is in agreement with findings of Chaijan et al. ${ }^{57}$ They reported that, the phenolic compounds had less effect in lowering enzymatic hydrolysis of fish muscle. Bensid et al..$^{51}$ reported that, the effect of polyphenols from thyme, oregano and clove extracts leads to lower the formation of free fatty acid. The prime factor of hydrolytic rancidity in fish during ice storage takes place as a result of endogenous enzyme namely, lipases and phospholipases activity and later on, microbial activity should be important, so that FFA formation should mostly be produced as a result of bacterial and enzyme activity. The inhibitory effect of plant polyphenols on endogenous enzyme activity in fish based muscle system occurred in first stage (d2-6) while antimicrobial effect of polyphenols led in the second stage (d10-23) to a lower free fatty acid formation.

Changes in trim ethylamine nitrogen (TMA-N): Trim ethylamine oxide (TMAO) is the compound which occurs naturally in most of the marine fishes responsible for their characteristic fishy odour and flavor. Trimethylamine is the bacteriologically degraded product from trim ethylamine oxide (TMA-O) ${ }^{58}$ Trimethylamine (TMA) level in fish is an important factor in the subjective evaluation of fish quality because of its close association with fish spoilage. ${ }^{59}$ Fish with a level beyond $10-15 \mathrm{mg}$ TMA-N/100g fish are considered as spoiled. ${ }^{60}$ In the present investigation, the percentage of reduction in TMA-N of mackerel with the effect of treatment with BHT, GSE and PSE on the day of sensory rejection with respect to untreated steaks (CSC) was found to be $38.74,25.39$ and $19.63 \%$ on the day of sensory rejection respectively. The results of the present study are in agreement with Gao et al. ${ }^{61}$ TMA-N production in fish and fishery products is due to enzymatic and microbial degradation of protein and non- protein nitrogenous compounds. The protein and non- protein nitrogenous content in fish depends on several factors such as age, sex, culture method and locality of fish in which it resides. ${ }^{62}$ The increase in TMA-N levels may result from domination of free amino acid, oxidation of amines and degradation of nucleotides by autolytic enzymes and microbial activity. ${ }^{63}$ The above results clearly indicated that, the polyphenolic compounds from GSE and PSE were effective in controlling TMA-N formation in steaks during ice storage. The results of the present study are in agreement with Lopez de Lacey et al. ${ }^{64}$ They monitored crude polyphenols from green tea extract and showed antimicrobial activity which lowered TMA-N formation in hake fillets during $15 \mathrm{~d}$ of storage.

Changes in total volatile base nitrogen (TVB-N): Total volatile basic nitrogen (TVB-N) levels have been recognized as useful indicators of seafood spoilage; under EU directive 95/149/EEC, the 
European Commission has specified that, the TVB-N level can be used, if sensory methods raise doubts about the freshness of seafood species. ${ }^{65}$ In the present investigation changes in TVB-N content with the effect of GSE and PSE during ice storage of Indian mackerel steaks are shown in Table. The treatment with GSE and PSE contributed to lowering TVB-N formation but GSE seems to be more effective in delaying or reducing the growth of bacteria which are involved in the production of basic compounds (TVB-N) in fish during ice storage. The percentage of reduction in TVB-N with the effect of treatment with BHT, GSE and PSE on the day of sensory rejection with respect to untreated steaks (CSC) was lowered by $29.56,22.17$ and $11.45 \%$ respectively on the day of sensory rejection. The present findings of antimicrobial action of polyphenols to lower TVB-N during ice storage are in agreement with the report published by Unalan et al. ${ }^{66}$ that, the pomegranate and rosemary extract helps to lower TVB-N formation in halibut fillets. Similar trends were reported by Quitral et al. ${ }^{67}$ on lowering TVB-N content of Chilean jack mackerel (Trachurus murphyi) during ice storage with the effect of rosemary and oregano polyphenols

Changes in pH: A change in $\mathrm{pH}$ of fish muscle is usually a good index for quality assessment. ${ }^{40}$ The changes in the $\mathrm{pH}$ of iced stored mackerel and steaks are presented in Table 20A, 20B and Figure 30A, 30B. Lactic acid generated in anoxic conditions from glycogen is the principal factor in lowering the post mortem $\mathrm{pH}$ in fish muscle. In the present study a marked increase in $\mathrm{pH}$ of all treated groups of whole mackerel and steaks during ice storage was observed and were in line with Shinde et al. ${ }^{68}$

Changes in microbiological characteristics: It has been estimated that about one third of world's food production is lost annually on account of microbial spoilage. Microorganism associated with aquatic products usually reflects the microbial population in the environment. In the present study changes in total plate count of steaks treated with GSE and PSE during ice storage for $15 \mathrm{~d}$ are presented in Table The results of the study showed that, the microbiological growth was significantly $(p<0.05)$ influenced by the dip treatment of mackerel and steaks with GSE and PSE. GSE extracts were found to be more effective in reducing total bacterial load of fish samples. The antibacterial property of GSE was reported to be due to the hydrophobic nature of phenolic compounds. ${ }^{27}$ Accumulation and attachments of these phenolics to the bacterial cytoplasmic membrane eventually lead to cell death. ${ }^{69}$ Other researchers also reported antimicrobial effects of GSE in restructured mutton slices (RMS) under aerobic and vacuum packaging conditions during refrigerated storage and result of the investigation revealed that reduction of total psychrophilic counts of GSE in both aerobic and vacuum packaged RMS is probably due to the antimicrobial activity of GSE. ${ }^{70}$

Changes in sensory characteristics: The objective of sensory testing is to measure the intrinsic sensory attributes of a sample through the analytic sensory perceptions of human assessors. The overall quality of seafood is comprised of both wholesomeness and sensory acceptability by the consumer. ${ }^{71}$ In the present investigation sensory attributes of mackerel and steaks during ice storage studies are depicted in Table 1. The mean panel scores of all the sensory characteristics were observed to decrease an increase in the storage period. The present study indicated that CSC reached a maximum limit of $9 \mathrm{~d}$ of ice storage and BHT, GSE and PSE treated steaks were in acceptable condition at the end of $15 \mathrm{~d}$ of ice storage. The results of the present study can be compared with the previous finding of Bennour et al. ${ }^{72}$ and Shinde et al., ${ }^{68}$ who reported that mackerel were in acceptable condition upto 6-9d during ice storage. The sensory attributes for mackerel and steaks treated with BHT, GSE and PSE showed a declining trend in sensory attributes, however, the deterioration was slow for treated samples compared to untreated control samples. Treated samples had a significant effect on the sensory attributes $(p<0.05)$ compared to untreated ones. Previous works demonstrated an increased shelf-life and enhancement of sensory quality of Indian mackerel with the treatment of aloevera and god fruit extracts as investigated by Winarni et al. ${ }^{73}$

\section{Conclusion}

The use of antioxidants during ice storage was used to improve shelf life of Indian mackerel steaks. However, the use of crude extracts at the level of 0.5 and $1 \mathrm{mg} / \mathrm{mL}$ doesn't give any bitter taste according to sensory assessment. Biochemical and microbiological analysis also showed that the use of $0.5 \mathrm{mg} / \mathrm{mL}$ of grape seed extract were found to be most effective $(\mathrm{P}<0.05)$ in controlling the rate of lipid oxidation and microbial spoilage.

\section{Acknowledgements}

None.

\section{Conflict of interest}

The author declares no conflict of interest.

\section{References}

1. Bremner HA. Towards practical definition of quality for food science. Crit Rev Food Sci Nutri. 2000;40(1):83-90.

2. Huisveld JHJ. Microbial and biochemical spoilage of foods: An overview. Int J Food Microbiol. 1996;33(1):1-18.

3. Boyd lc, Green DP, Giesbrecht FB, et al. Inhibition of oxidative rancidity in frozen cooked fish flakes by tert-butylhydroquinone and rosemary extract. J Sci Food Agric. 1993;61(1):87-93.

4. Chang SS, Ostric Matijasevic B, Hsieh OA, et al. Natural antioxidants from rosemary and sage. J Food Sci. 1977;42(4):1102-1106.

5. Spigno G, De Faveri DM. Antioxidants from grape stalks and marc: influence of extraction procedure on yield, purity and antioxidant power of the extracts. J Food Eng. 2007;78:793-801.

6. Amerine A, Joslyn MA. Composition of grapes. In: Amerine A, et al. editors. Table wines, the technology of their production.3rd ed. USA: University of California Press; 1967. p. 7-8.

7. Bertelli A, Falchi M, Lo Scalzo R, et al. EPR evaluation of the antiradical activity of wines containing high concentrations of resveratrol. Drugs Exp Clinical Res. 2004;30(3):111-115.

8. Fujii $\mathrm{H}$, Nakagawa $\mathrm{T}$, Nishioka $\mathrm{H}$, et al. Preparation, characterization, and antioxidative effects of oligomeric proanthocyanidin- L-cysteine complexes. J Agri Food Chem. 2007;55(4):1525-1531.

9. Kedage VV, Tilak JC, Dixit GB, et al. A study of antioxidant properties of some varieties of grapes (Vitis vinifera L.). Crit Rev Food Sci Nut. 2007;47(2):175-185.

10. Heinonen IM, Meyer AS, Frankel EN. Antioxidant activity of berry phenolics on human low-density lipoprotein and liposome oxidation. $J$ Agric Food Chem. 1998;46(10):4107-4112.

11. Palma M, Taylor LT. Extraction of polyphenolic compounds from grape seeds with near critical carbon dioxide. J Chromato. 1999;849(1):117124. 
12. Taguri T, Tanaka T, Kouno I. Antimicrobial activity of 10 different plant polyphenols against bacteria causing food-borne disease. Biol Pharma Bull. 2004;27(12):1965-1969.

13. Pokorny J. Are natural antioxidants better and safer than synthetic antioxidants? Eur J Lipid Sci Technol. 2003;109(6):629-642.

14. Bañón $\mathrm{S}$, Díaz $\mathrm{P}$, Rodríguez $\mathrm{M}$, et al. Ascorbate, green tea and grape seed extracts increase the shelf life of low sulphite beef patties. Meat Sci. 2007;77(4):626-633.

15. Adebiyi A, Ganesan Adaikan P, Prasad RN. Tocolytic and toxic activity of papaya seed extract on isolated rat uterus. Life Sci. 2003;74(5):581-592.

16. Yen $\mathrm{G}, \mathrm{Wu}$ J. Antioxidant and radical scavenging properties of extracts from Ganoderma tsugae. Food chem. 1999;65:375-379.

17. Oyaizu M. Studies on product browning reaction: antioxidant activity of products of browning reaction prepared from glucosamine. J of Nutrition. 1986;44:307-315.

18. Osawa T, Namiki M. Natural antioxidants isolated from eucalyptus leaf waxes. J Agric Food Chem. 1985;33(5):777-780.

19. AOAC. Official Methods of Analysis of AOAC international.17th ed. Gaitherburg, Mary land, USA: Association of official and analytical chemists international; 2000 .

20. Richards MP, Hultin HO. Contribution of blood and blood components to lipid oxidation in fish muscle. J Agric Food Chem. 2002;50(3):555-564.

21. Buege JA, Aust SD. Microsomal lipid peroxidation. Method in Enzymology. 1978;52:302-310.

22. Conway EJ. Micro diffusion analysis of volumetric error. 5th ed. Boca Raton, London: CRC Press; 1962. p. 103-137.

23. APHA. Standard methods for the examination of water and waste water 18th ed. American public health association, Washington, USA: DC; 1992.

24. Surendran PK, Nirmala T, Nambiar VN, et al. Laboratory techniques for identification of bacteria in fish and fishery Products. CIFT; 1997. 19 p.

25. Meilgaard M, Civille GV, Carr BT. Sensory evaluation techniques. 3rd ed. Boca Raton, New York, USA: CRC Press; 1999. 387 p.

26. Shimada K, Fujikawa K, Yahara K, et al. Antioxidative properties of xanthan on the anti-oxidation of soybean oil in cyclodextrin emulsion. $J$ Agric Food Chem. 1992;40(6):945-948.

27. Jacob JK, Hakimuddin F, Paliyath G, et al. Antioxidant and anti proliferative activity of polyphenols in novel high-polyphenol grape lines. Food Res Int. 2008;41:419-428.

28. Arora A, Nair MG, Strasburg GM. Structure-activity relationships for antioxidant activities of a series of flavonoids in a liposomal system. Free Rad Biol Med. 1998;24(9):1355-1363.

29. Saito M, Hosoyama H, Ariga T, et al. Anti ulcer activity of grape seed extract and procyanidins. J Agric Food Chem. 1998;46(4):1460-1464.

30. Zhou K, Wang H, Mei W, et al. Antioxidant activity of papaya seed extracts. Molecules. 2011;16(8):6179-6192.

31. Thiago ASA, Nelson LA, Elba LCA, et al. A new approach to study medicinal plants with tannins and flavanoids contents from the local knowledge. J Ethnopharmacol. 2008;120(1):72-80.

32. Medina I, Gallardo JM, Gonzalez MJ, et al. Effect of molecular structure of hydroxycinnamic acids and catechins on the antioxidant effectiveness in minced fish muscle. J Agric Food Chem. 2007;55(10):3889-3895.

33. Zhang A, Fang Y, Wang H, et al. Free-radical scavenging properties and reducing power of grape cane extracts from 11 selected grape cultivars widely grown in China. Molecules. 2011;16(12):10104-10122.
34. Gao J, Igarashi K, Nukina M. Three New Phenylethanoid Glycosides from Caryopteris incana and their antioxidative activity. Chem Pharm Bull. 2000;48(7):1075-1078.

35. Kosem N, Han YH, Moongkarndi P. Antioxidant and cytoprotective activities of methanolic extract from Garcinia mangostana hulls. Sci Asia. 2007;33:283-292.

36. Yu L, Zhao M, Yang B, et al. Phenolics from hull of Garcinia mangostana fruit and their antioxidant activities. Food Chem. 2007;104:176-181.

37. Fernández J, Pérez-Álvarez JA, Fernández-López JA. Thiobarbituric acid test for monitoring lipid oxidation in meat. Food Chem. 1997:59:345353.

38. Zarena AS, Sankar K. Screening of xanthone from mangosteen (Garcinia mangostana L.) peels and their effect on cytochrome reductase and phosphomolybdenum activity. J Nat Prod. 2009;2:23-30.

39. Ramchandani AG, Chettiyar RS, Pakhale SS. Evaluation of antioxidan and anti-initiating activities of crude polyphenolic extracts from seedless and seeded Indian grapes. Food Chem. 2010;119(1):298-305.

40. Jayaprakasha GK, Singh RP, Sakariah KK. Antioxidant activity of grape seed extracts on peroxidation models. J Agric Food Chem . 2001;55:10181022

41. Gazzani G, Papetti A, Massolini G, et al. Antioxidative and pro- oxidant activity of water soluble components of some common diet vegetables and the effect of thermal treatment. J Agric Food Chem. 1998;46(4):4118 4122

42. Nicoli MC, Anese M, Parpinel M. Influence of processing on the antioxidant properties of fruit and vegetables. Trends Food Sci Technol. 1999;10(3):94-100.

43. Castenmiller JJ, Linssen JP, Heinonen IM, et al. Antioxidant properties of differently processed spinach products. Nahrung Food. 2002;46(4):290 293.

44. Talcott ST, Howard LR, Brenes CH. Antioxidant changes and sensory properties of carrot purée processed with and without periderm tissue. $J$ Agric Food Chem. 2000;48(4):1315-1321.

45. Yen GC, Duh PD, Tsai CL. Relationship between antioxidant activity and maturity of peanut hulls. J Agric Food Chem. 1993;41(1):67-70.

46. Azizah AH, Vruslawati NMN, Sweetee T. Extraction and characterization of antioxidant from cocoa by-products. Food Chem. 1999;64:199-202.

47. Saeedeh A, Vishalakshi D, Asna U. Evaluation of antioxidant activity of some plant extracts and their heat, $\mathrm{pH}$ and storage stability. Food Chem 2007;100(3):1100-1105.

48. Gopakumar K. Textbook of fish processing technology. India: Indian Council of Agriculture Research; 2002. 491 p.

49. Jianyun CS, Xiaofei Y, Yongkang L, et al. Grape seed and clove extract as natural antioxidants in silver carp fillets during chill storage: Effect on lipid and protein oxidation. Food Control. 2014;40:134-139.

50. Sulochanan B. Effect of natural antioxidant sources on the quality upgradation of processed products from Indian mackerel (Rastrelliger kanagurta). Ph.D thesis, Cochin, India: Cochin University of Science and Technology; 2008.

51. Bensid A, Ucar Y, Bendeddouche B, et al. Effect of the icing with thyme, oregano and clove extracts on quality parameters of gutted and beheaded anchovy (Engraulis encrasicholus) during chilled storage. Food Chem. 2004; 15:681-686

52. Iglesias J, Pazos M, Torres JL, et al. Antioxidant mechanism of grape procyanidins in muscle tissues: Redox interactions with endogenous ascorbic acid and $\alpha$-tocopherol. Food Chem. 2012;134(4):1767-1774. 
53. Rababah TM, Ereifej KI, Al-Mahasneh MA, et al. Effect of plant extracts on photochemical properties of chicken breast meat cooked using conventional electric oven or microwave. Poultry Sci. 2006;85(1):148154.

54. Shirahigue LD, Plata-Oviedo M, Alencar SM, et al. Wine industry residue as antioxidant in cooked chicken meat. Int J Food Sci and Technol. 2010;45(5):863-870.

55. Jongberg S, Tørngren MA, Gunvig A, et al. Effect of green tea or rosemary extract on protein oxidation in Bologna type sausages prepared from oxidatively stressed pork. Meat Sci. 2013;93(3):538-546.

56. Brannan RG, Mah E. Grape seed extract inhibit lipid oxidation in muscle from different species during refrigerated and frozen storage and oxidation catalyzed by peroxynitrite and iron/ ascorbate in pyrogallol red model system. Meat Sci. 2007;77(4):540-546.

57. Chaijan M, Benjakul S, Visessanguan S, et al. Changes of lipids in sardine (Sardinella gibbosa) muscle during iced storage. Food Chem. 2006;99:83-91.

58. Huss HH. Quality and quality changes in fresh fish. FAO Fisheries Technical Paper; 1995. 348 p.

59. Chang GW, Chang WL, Lew KBK. Trimethylamine-specific electrode for fish quality control. J Food Sci. 1976;41(3):723-728.

60. Govindan TK. Fish processing technology. Oxford and IBH Publishing; 1985. $251 \mathrm{p}$

61. Gao M, Feng L, Jiang T, et al. The use of rosemary extract in combination with nisin to extend the shelf life of pompano (Trachinotus ovatus) fillet during chilled storage. Food Control. 2014;37:1-8.

62. Delbarre-Ladrat C, Chéret R, Taylor R, et al. Trends in postmortem aging in fish: understanding of proteolysis and disorganization of the myofibrillar structure. Crit Rev Food Sci Nutr. 2006;46(5):409-421.

63. Ocano-Higuera VM, Maeda-Martinez AN, Ruiz-Bustos E. Freshness assessment of ray fish stored in ice by biochemical, chemical and physical methods. Food Chem. 2011;125:49-54.
64. Lopez De Lacey AM, Lopez-Caballero ME, Montero P. Agar films containing green tea extract and probiotic bacteria for extending fish shelf-life. Food Sci Technol. 2014;55(2):669-664.

65. EU (European Union). Causes of detentions and rejections in international fish trade. 2nd ed. European Union, Rome: Blackwell Scientific Publications; 2005. p. 152-163.

66. Unalan İU, Dalgaard P, Korel F. Effect of pomegranate (Punica granutum) and rosemary (Rosmarinus officinalis L.) extracts on shelf-life for chilled greenland halibut (Reinhardtius hippoglossoides) fillets in modified atmosphere packaging at $2^{\circ} \mathrm{C}$. Food Chem. 2011;112:26-29.

67. Quitral V, Donoso ML, Ortiz J, et al. Chemical changes during the chilled storage of Chilean jack mackerel (Trachurus murphyi): Effect of a plantextract icing system. Food Sci Technol. 2009;42(8):1450-1454.

68. Shinde P, Reddy V, Shelar P, et al. The quality changes in Indian mackerel during ice storage, following treatment with natural extracts. Cont J Food Sci Technol. 2012;6(3):19-26.

69. Lin YT, Labbe RG, Shetty K. Inhibition of Listeria monocytogenes in fish and meat systems by use of oregano and canberry phytochemical synergies. Appl Enviro Microbio. 2004;70(9):5672-5678.

70. Ahn J, Grün IU, Mustapha A. Antimicrobial and antioxidant activities of grape seed extracts in vitro in ground beef. J Food Protec. 2004;67(1):148155.

71. Sikorski ZE, Sunpan B. Preservation of seafood. In: Shahidi F, et al. editors. Sea foods: chemistry, processing technology and quality. 5th ed. Blackie Academic Press and Professional; 1994. p. 169-195.

72. Bennour M, Marrakachi A, Bouchriti N, et al. Chemical and microbiological assessment of mackerel (Scomber scombrus) stored in ice. J Food Prot. 1991;54(10):789-792.

73. Winarni TA, Eko S, Ismail MA, et al. Effect of aloe vera and crown of God fruit on sensory, chemical, and microbiological attributes of Indian mackerel during ice storage. Intl Food Res J. 2012;19(1):119-125. 